\title{
Is Perineural Invasion of Head and Neck Squamous Cell Carcinomas Linked to Tobacco Consumption?
}

\author{
Philipp Baumeister, MD ${ }^{1,2}$, Christian Welz, MD ${ }^{3}$, \\ Christian Jacobi, MD', and Maximilian Reiter, MD'
}

(S)AGE

No sponsorships or competing interests have been disclosed for this article.

\begin{abstract}
Perineural invasion (PNI) is an underrecognized path of cancer spread, and its causes and mechanisms are poorly understood. Recent research indicates a mutual attraction of neuronal and cancer cells, largely dependent on neurotrophic factors and their receptors. Interestingly, the release of neurotrophic factors occurs upon cigarette smoke/nicotine exposure in a dose-dependent manner, and serum levels correlate with current smoking, number of smoking years, and smoking severity. Among cell types capable of neurotrophic factors secretion are lung and oral fibroblasts. In our study of 178 patients with head and neck squamous cell carcinoma, tumors of current and former smokers showed PNI significantly more often than tumors of never smokers. Moreover, PNI was a marker for aggressive tumor growth. Surprisingly, PNI was more significant for survival than pl6 status. Our study warrants further research on $\mathrm{PNI}$ in head and neck squamous cell carcinoma with special emphasis on the impact of tobacco consumption to identify suitable candidates for therapeutic interventions.
\end{abstract}

\section{Keywords}

perineural invasion, head and neck squamous cell carcinoma, tobacco consumption, neurotrophic factors

Received August 2, 2017; revised October 19, 2017; accepted December 5, 2017.

$\mathrm{P}$ erineural invasion (PNI) represents a specific path of cancer spread in a variety of solid malignancies, including head and neck squamous cell carcinoma (HNSCC), and is associated with poor prognosis. ${ }^{1-4}$ Perineural growth occurs in a discontinuous manner. Cancers spread centripetally toward the central nervous system, forming skip lesions. ${ }^{5}$ Thus, PNI-positive (Pn1) HNSCCs may be particularly difficult to resect. ${ }^{6}$ PNI also represents a characteristic of more aggressive carcinomas. ${ }^{7}$

Causes and mechanisms of PNI are poorly understood. Recent research indicates that a mutual tropism between pancreatic cancer cells and neurons induces PNI. ${ }^{8}$ Deborde et al discovered a subpopulation of Schwann cells in murine and human specimens that associate with pancreatic cancer cells. ${ }^{9}$ In cocultures with dorsal root ganglion extracts, these Schwann cells directed cancer cells to migrate toward nerves in a contact-dependent manner. The neural cell adhesion molecule (NCAM), activated by hemophilic binding, was expressed on both Schwann and cancer cells. In their study, cancer cell dispersion and directed invasion of cancer cells were dependent on NCAM expression of Schwann cells. NCAM is expressed by $93 \%$ of Pn1-HNSCCs. ${ }^{10}$ NCAM is also an alternative receptor of glial cell-derived neurotrophic factor (GDNF), and cancer cell invasion of neuronal structures is partially dependent of GDNF secretion of neuronal cells. ${ }^{11,12}$ Furthermore, nerve growth factor (NGF), brain-derived neurotrophic factor (BDNF), and their respective receptors, tropomyosin-related kinase $\mathrm{A}$ and $\mathrm{B}$ (TrkA and TrkB), are involved in PNI. ${ }^{13}$

Very recent studies indicated a role of the neurotrophic factors in smoking and the development of nicotine dependence. ${ }^{14,15}$ The aim of our study was to investigate possible associations between smoking and PNI in HNSCC.

\section{Methods}

We retrospectively analyzed PNI in the HNSCC of patients prospectively enrolled in our department in an ongoing study about risk factors of HNSCC. ${ }^{16}$ Patients were interviewed about smoking habits on the day before surgical resection of their tumors. Former smokers were defined as patients who stopped smoking at least 1 year before diagnosis. All patients signed an informed consent regarding the use of clinical data. The study was approved by the Ethics

'Department of Otorhinolaryngology-Head and Neck Surgery, LudwigMaximilians-University, Munich, Germany

${ }^{2}$ Clinical Cooperation Group-Personalized Radiotherapy in Head and Neck Cancer, Helmholtz Center, Munich, Germany

${ }^{3}$ Department of Otorhinolaryngology-Head and Neck Surgery, GeorgAugust-University, Göttingen, Germany

\section{Corresponding Author:}

Philipp Baumeister, MD, Department of Otorhinolaryngology-Head and Neck Surgery, Ludwig-Maximilians-University, Marchioninistr. 15, Munich, Bavaria 8I377, Germany.

Email: Philipp.Baumeister@med.uni-muenchen.de 
Committee of the Medical Faculty of Ludwig-MaximiliansUniversity, Munich, Germany. Statistical analysis performed with SPSS 24 (IBM, Chicago, Illinois).

\section{Results}

A total of 178 cases were analyzed. Clinical data are shown in Table I: $27.5 \%(n=49)$ of tumors were diagnosed as Pn1 and $72.5 \%(\mathrm{n}=129)$ as Pn0. PNI was detected significantly more often in HNSCC of current $(34.7 \%, \mathrm{n}=95)$ and former $(26.1 \%, \mathrm{n}=46)$ smokers as compared with never smokers $(10.3 \%, \mathrm{n}=29 ; P=.036$, chi-square test; see Figure I). Spearman correlation between smoking status and PNI was also significant $(P=.014)$.

In the p16-negative group, PNI was found in the tumors of $30.9 \%, 25.0 \%$, and $0 \%$ of current, former, and never smokers, respectively; these percentages were $19.0 \%$, $17.6 \%$, and $4.8 \%$, respectively, in the p16-positive group. Overall, $26.4 \%$ of p16-negative and $12.9 \%$ of p16-positive HNSCCs were diagnosed as Pn1 $(P=.045$, chi-square test $)$ Noteworthy, Pn1-HNSCC significantly more often showed additional signs of aggressive growth in terms of lymphovascular invasion $(40.0 \%$ vs $17.9 \%, P=.001$, chi-square test), vein invasion $(64.3 \%$ vs $23.0 \%, P=.001$, chi-square test), and extranodal extension $(37.3 \%$ vs $12.7 \%, P=.025$, chi-square test).

Median follow-up was 2.0 years (range, 0.6-7.0 years). Patients with Pn1-HNSCC had a significantly shorter diseasefree survival (3.9 years [95\% CI, 2.9-4.9] vs 5.1 years [ $95 \%$ CI, 4.5-5.7], $P=.013276$, log-rank test) and overall survival (3.0 years [95\% CI, 2.2-3.8] vs 5.4 years [95\% CI, 4.8-5.9], $P=.000004$, log-rank test; see Figure 2). Surprisingly, patients with p16-positive HNSCC did not have a longer disease-free survival $(5.0$ years [95\% CI, 4.3-5.7] vs 4.1 years [95\% CI, 3.6-4.6], $P=.170799$, log-rank test) within this follow-up period. Overall survival of patients with p16positive HNSCC was significantly longer (5.8 years [95\% CI, 5.2-6.3] vs 3.7 years [95\% CI, 3.2-4.3], $P=.001297$, logrank test). In multivariate analysis, PNI $(P=.000661$, Cox regression) was more significant for overall survival when compared with p16 ( $P=.006185$, Cox regression).

\section{Discussion}

Our results suggest an association between tobacco consumption and PNI in HNSCC. Furthermore, PNI was related to established characteristics of aggressive tumor growth.

PNI is dependent on the presence of neurotrophic factors. ${ }^{4}$ Higher expression levels of NGF and its receptor TrkA were detected in Pn1 versus Pn0 HNSCC. ${ }^{17}$ TrkB and GDNF were more expressed in HNSCC tumor specimens than in surrounding mucosa. Blockade of NGF/TrkA signaling decreased proliferation of cancer cells. ${ }^{18,19}$ GDNF increased matrix metalloproteinase expression and, thus, migration of oral cancer cells. ${ }^{20}$ As reviewed recently, BDNF/TrkB signaling regulates cell migration, invasion, epithelial-to-mesenchymal transition, and cisplatin resistance in $\mathrm{HNSCC}^{21}$
Table I. Clinical Data.

n (\%)

\begin{tabular}{|c|c|}
\hline \multicolumn{2}{|l|}{ Localization } \\
\hline Oral cavity & $33(18.5)$ \\
\hline Oropharynx & $128(71.9)$ \\
\hline Hypopharynx & $13(7.3)$ \\
\hline Larynx & $4(2.2)$ \\
\hline \multicolumn{2}{|l|}{ Smoking } \\
\hline Current & $29(16.3)$ \\
\hline Former & $46(25.8)$ \\
\hline Never & $95(53.4)$ \\
\hline N/A & $8(4.5)$ \\
\hline \multicolumn{2}{|l|}{ T-staging ${ }^{\mathrm{a}}$} \\
\hline PTI & $23(12.9)$ \\
\hline pT2 & $78(43.8)$ \\
\hline pT3 & $66(37.1)$ \\
\hline $\mathrm{pT} 4 \mathrm{a}$ & $10(5.6)$ \\
\hline pTx & I (0.6) \\
\hline \multicolumn{2}{|l|}{$\mathrm{N}$-staging ${ }^{\mathrm{a}}$} \\
\hline $\mathrm{pN} 0$ & $52(29.2)$ \\
\hline $\mathrm{pNI}$ & $22(12.4)$ \\
\hline $\mathrm{pN} 2 \mathrm{a}$ & $16(9.0)$ \\
\hline $\mathrm{pN} 2 b$ & $47(26.4)$ \\
\hline $\mathrm{pN} 2 \mathrm{c}$ & $22(12.4)$ \\
\hline $\mathrm{pN} 3$ & $3(1.7)$ \\
\hline $\mathrm{pNx}$ & $16(9.0)$ \\
\hline \multicolumn{2}{|l|}{ pl6 } \\
\hline Positive & $62(34.4)$ \\
\hline Negative & $87(48.9)$ \\
\hline N/A & $29(16.3)$ \\
\hline \multicolumn{2}{|c|}{ Perineural invasion } \\
\hline Pn0 (absent) & $129(72.5)$ \\
\hline PnI (present) & $49(27.5)$ \\
\hline \multicolumn{2}{|c|}{ Lymphovascular invasion } \\
\hline LO (absent) & $106(59.6)$ \\
\hline LI (present) & $70(39.3)$ \\
\hline N/A & $2(1.1)$ \\
\hline \multicolumn{2}{|l|}{ Vein invasion } \\
\hline V0 (absent) & $161(90.4)$ \\
\hline VI (present) & $14(7.9)$ \\
\hline N/A & $3(1.7)$ \\
\hline \multicolumn{2}{|c|}{ Extranodal extension } \\
\hline Positive & $5 I(28.7)$ \\
\hline Negative & $5 \mathrm{I}(28.7)$ \\
\hline $\mathrm{NO} \mathrm{b}^{\mathrm{b}}$ & $67(37.6)$ \\
\hline N/A & $9(5.0)$ \\
\hline \multicolumn{2}{|l|}{ Grading } \\
\hline GI & $4(2.2)$ \\
\hline $\mathrm{G} 2$ & $57(32.0)$ \\
\hline G3 & II (65.7) \\
\hline
\end{tabular}

Abbreviation: N/A, not available. ${ }^{a}$ AJCC Cancer Staging Manual, 7th Edition. ${ }^{\mathrm{b}}$ Clinically or pathologically NO. 


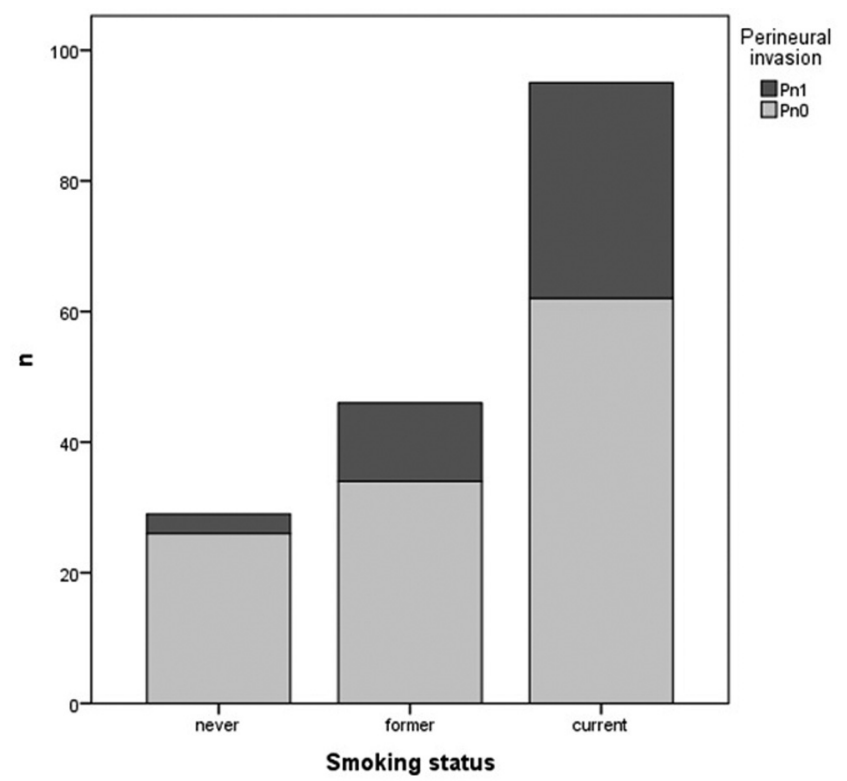

Figure I. Percentage of perineural invasion-positive carcinomas $(\mathrm{PnI})$ in relation to smoking status. Pn0, negative.

There is growing evidence of an association between neurotrophic factors and smoking. BDNF influences nicotine dependence. Current smoking and higher number of smoking years were associated with higher BDNF serum levels. ${ }^{14}$ BDNF serum levels also correlated with exhaled carbon monoxide and, therefore, smoking severity. ${ }^{22} \mathrm{BDNF}$ is released from blood platelets exposed to cigarette smoke in a dose-dependent manner. ${ }^{23}$ It is secreted by airway smooth muscle cells and lung fibroblasts upon cigarette smoke/nicotine exposure. ${ }^{24,25}$ Dudás et al showed that oral fibroblasts are capable of producing BDNF. ${ }^{26}$
In summary, a link among tobacco consumption, neurotrophic factors, and PNI in HNSCC seems plausible, even though other causative factors may play a role. Our results indicate a link between smoking and PNI-to our knowledge for the first time - and so warrant further investigations into proposed connections, not least to identify suitable candidates and targets for therapeutic interventions.

\section{Author Contributions}

Philipp Baumeister, acquisition, analysis of data, drafting the work, final approval, accountable for all aspects of the work; Christian Welz, acquisition, analysis of data, drafting the work, final approval; Christian Jacobi, drafting the work, revising it critically for important intellectual content, final approval; Maximilian Reiter, acquisition, analysis of data, drafting the work, final approval, accountable for all aspects of the work.

\section{Disclosures}

Competing interests: None.

Sponsorships: None.

Funding source: None.

\section{References}

1. Ceyhan GO, Demir IE, Altintas B, et al. Neural invasion in pancreatic cancer: a mutual tropism between neurons and cancer cells. Biochem Biophys Res Commun. 2008;374:442447.

2. Ayala GE, Dai H, Ittmann M, et al. Growth and survival mechanisms associated with perineural invasion in prostate cancer. Cancer Res. 2004;64:6082-6090.

3. Huh JW, Kim HR, Kim YJ. Prognostic value of perineural invasion in patients with stage II colorectal cancer. Ann Surg Oncol. 2010;17:2066-2072.
A

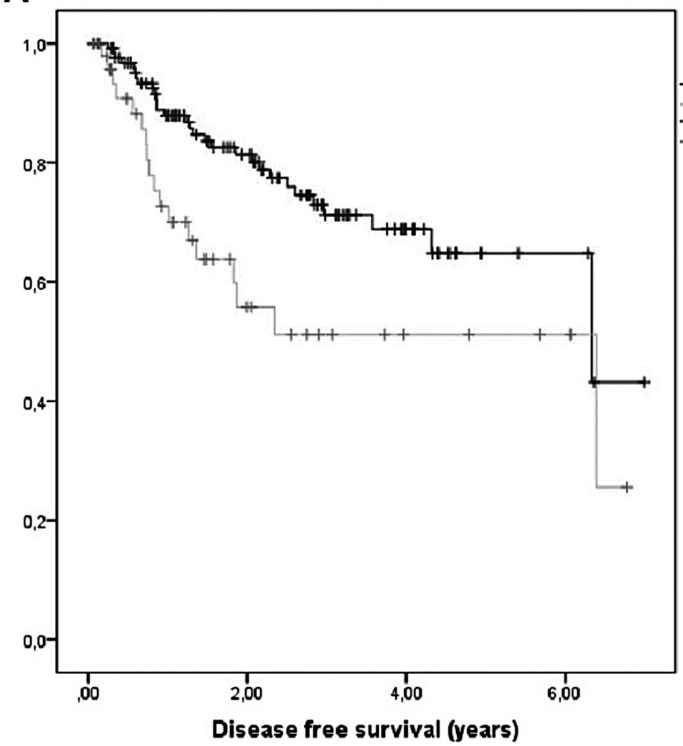

B

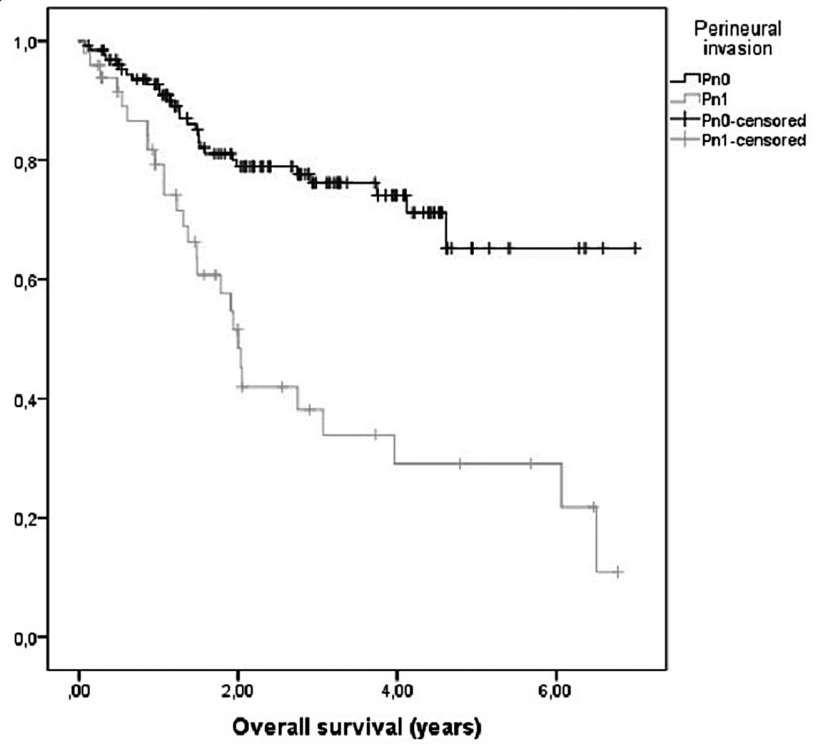

Figure 2. Disease-free survival (A) and overall survival (B) in dependence of perineural invasion. Pn0, negative; PnI, positive. 
4. Roh J, Muelleman T, Tawfik O, Thomas SM. Perineural growth in head and neck squamous cell carcinoma: a review. Oral Oncol. 2015;51:16-23.

5. Liebig C, Ayala G, Wilks JA, Berger DH, Albo D. Perineural invasion in cancer: a review of the literature. Cancer. 2009; 115:3379-3391.

6. Yousem DM, Gad K, Tufano RP. Resectability issues with head and neck cancer. AJNR Am J Neuroradiol. 2006;27:2024-2036.

7. Tai SK, Li WY, Yang MH, Chu PY, Wang YF, Chang PM. Perineural invasion as a major determinant for the aggressiveness associated with increased tumor thickness in t1-2 oral tongue and buccal squamous cell carcinoma. Ann Surg Oncol. 2013;20:3568-3574.

8. Ceyhan GO, Demir IE, Altintas B, et al. Neural invasion in pancreatic cancer: a mutual tropism between neurons and cancer cells. Biochem Biophys Res Commun. 2008;374:442-447.

9. Deborde S, Omelchenko T, Lyubchik A, et al. Schwann cells induce cancer cell dispersion and invasion. J Clin Invest. 2016;126:1538-1554.

10. Vural E, Hutcheson J, Korourian S, Kechelava S, Hanna E. Correlation of neural cell adhesion molecules with perineural spread of squamous cell carcinoma of the head and neck. Otolaryngol Head Neck Surg. 2000;122:717-720.

11. Paratcha G, Ledda F, Ibáñez CF. The neural cell adhesion molecule NCAM is an alternative signaling receptor for GDNF family ligands. Cell. 2003;113:867-879.

12. Bakst RL, Lee N, He S, et al. Radiation impairs perineural invasion by modulating the nerve microenvironment. PLoS One. 2012;7:e39925.

13. Liebig C, Ayala G, Wilks JA, Berger DH, Albo D. Perineural invasion in cancer: a review of the literature. Cancer. 2009; 115:3379-3391.

14. Jamal M, Van der Does W, Elzinga BM, Molendijk ML, Phennix BW. Association between smoking, nicotine dependence, and BDNF Val66Met polymorphism with BDNF concentrations in serum. Nicotine Tob Res. 2015;17:323-329.

15. Kim KW, Won YL, Ko KS, Roh JW. Smoking habits and neuropeptides: adiponectin, brain-derived neurotrophic factor, and leptin levels. Toxicol Res. 2014;30:91-97.
16. Baumeister P, Reiter M, Welz C, Becker S, Betz C, Harréus U. Surgically treated oropharyngeal cancer: risk factors and tumor characteristics. J Cancer Res Clin Oncol. 2014;140: 1011-1019.

17. Kolokythas A, Cox DP, Dekker N, Schmidt BL. Nerve growth factor and tyrosine kinase A receptor in oral squamous cell carcinoma: is there an association with perineural invasion? J Oral Maxillofac Surg. 2010;68:1290-1295.

18. Yilmaz T, Jiffar T, de la Garza G, et al. Theraputic targeting of Trk supresses tumor proliferation and enhances cisplatin activity in HNSCC. Cancer Biol Ther. 2010;10:644-653.

19. Chuang JY, Tsai CF, Chang SW, et al. Glial cell line-derived neurotrophic factor induces cell migration in human oral squamous cell carcinoma. Oral Oncol. 2013;49:1103-1112.

20. Ye Y, Dang D, Zhang J, et al. Nerve growth factor links oral cancer progression, pain, and cachexia. Mol Cancer Ther. 2011;10:1667-1676.

21. de Morales JK, Wagner VP, Fonseca FP, et al. Uncovering the role of brain-derived neurotrophic factor/tyrosine kinase receptor B signaling in head and neck malignancies [published online June26, 2017]. J Oral Pathol Med. doi:10.1111/jop.12611

22. Zhang XY, Tan YL, Chen DC, et al. Effects of cigarette smoking and alcohol use on neurocognition and BDNF levels in a Chinese population. Psychopharmacology (Berl). 2016;233:435-445.

23. Amadio P, Baldassarre D, Sandrini L, Weksler BB, Tremoli E, Barbieri SS. Effect of cigarette smoke on monocyte procoagulant activity: focus on platelet-derived brain-derived neurotrophic factor (BDNF). Platelets. 2017;28:60-65.

24. Sathish V, Vanoosten SK, Miller BS, et al. Brain-derived neurotrophic factor in cigarette smoke-induced airway hyperreactivity. Am J Respir Cell Mol Biol. 2013;48:431-438.

25. Wongtrakool C, Grooms K, Bijli KM, Crothers K, Fitzpatrick AM, Hart CM. Nicotine stimulates nerve growth factor in lung fibroblasts through an NFKB-dependent mechanism. PLoS One. 2014;9:e109602.

26. Dudás J, Bitsche M, Schartinger V, Falkeis C, Sprinzl GM, Riechelmann H. Fibroblasts produce brain-derived neurotrophic factor and induce mesenchymal transition of oral tumor cells. Oral Oncol. 2011;47:98-103. 